\title{
Differences in androgens of HIV positive patients with and without Kaposi sarcoma
}

\author{
N Christeff, C Winter, S Gharakhanian, N Thobie, E Wirbel, D Costagliola, \\ E A Nunez, W Rozenbaum
}

\begin{abstract}
Aim-Since most forms of Kaposi sarcoma are much more common in men than in women, the aim of this study was to examine serum concentrations of sex steroids in HIV positive men with and without Kaposi sarcoma.

Methods-Blood samples from 34 HIV positive men without Kaposi sarcoma (KS -) and 28 with Kaposi sarcoma (KS +) and from 35 HIV negative men (controls) were analysed for adrenal and gonadal steroids. Further analysis was done in subgroups classified by CD4 lymphocyte counts.

Results-KS + patients had significantly higher serum dehydroepiandrosterone (DHEA) and testosterone concentrations than the KS - patients, and their DHEA, DHEA sulphate, testosterone, and androstenedione values were higher than in the controls. The KS + patients with more than 500 CD4 lymphocytes per $\mathrm{mm}^{3}$ had significantly higher serum DHEA, DHEA sulphate, and testosterone than the KS patients with the same CD4 counts; those with 500-200 CD4 cells $/ \mathrm{mm}^{3}$ had higher serum DHEA and testosterone than the equivalent $\mathrm{KS}$ - men; and those with $<200$ CD4 cells $/ \mathrm{mm}^{3}$ had raised DHEA only compared with KS - men. Both KS + and KS - men had higher serum progesterone and oestradiol than the controls. Glucocorticoids were not significantly altered. Conclusions-The high androgen levels in $\mathrm{KS}+$ patients, particularly in the early stages of the disease ( $\left.>500 \mathrm{CD} 4 \mathrm{cells} / \mathrm{mm}^{3}\right)$, may affect the immune system by inducing an abnormal cytokine profile, or by increasing $T 8$ proliferation and activation, or both. This raises the question of the relationship between androgens and $\mathrm{Ka}-$ posi sarcoma.

(f Clin Pathol 1995;48:513-518)
\end{abstract}

Service des Maladies Infectieuses, Hôpital Rothschild, 33

Boulevard de Picpus, 75012 Paris, France

$S$ Gharakhanian

E Wirbel

W Rozenbaum

B3E, U263 INSERM et SC4, Faculté de Médecine SaintAntoine, 75571 Paris, France

D Costagliola

Correspondence to: Dr Névéna Christeff.

Accepted for publication: 3 November 1994 is associated with HIV infection, is also exvelopment of Kaposi lesions. Various cytokines,
The epidemic form of Kaposi sarcoma, which ceptionally common among male patients, ${ }^{12}$ and homosexual and bisexual men are 10 times more at risk. ${ }^{3}$ Certain factors favour the de-

Most forms of Kaposi sarcoma are much more common in men than in women-the ratio is particularly IL6, can act as autocrine/paracrine growth factor for AIDS associated Kaposi sarcoma. ${ }^{45}$ Glucocorticoids also favour the formation of Kaposi lesions. ${ }^{6}$ There have been reports ${ }^{7}$ of Kaposi sarcoma developing during the treatment of HIV patients with corticoids. The incidence of this condition began to increase with the use of immunosuppressive therapy for transplant recipients. ${ }^{8}$ Experimental studies also show that lesions resembling those of Kaposi sarcoma develop in male transgenic mice, but not in females. ${ }^{9}$

There is now general agreement that the steroid hormone profile of patients infected with HIV changes during the course of the viral infection. ${ }^{10-14}$ The serum concentrations of cortisol are normal or slightly high at all stages of HIV infection. ${ }^{111314}$ By contrast, androgen levels appear to be closely correlated with the stage of HIV infection. ${ }^{14}$ Asymptomatic HIV positive men (stages II and III) in general have high serum concentrations of androgens (dehydroepiandrosterone (DHEA), androstenedione, testosterone), whereas those with AIDS have subnormal androgen concentrations. There is also evidence for a relationship between CD4 count and serum DHEA or DHEA sulphate values in HIV infected men at risk of progression to AIDS. ${ }^{15}$ These changes in hormone concentrations, particularly of the androgen profile, during the course of HIV infection might result in significant alterations in immune competence, especially cytokine profiles and $\mathrm{T}$ cell activity and function. ${ }^{1617}$ Androgens, such as DHEA and DHEA sulphate, enhance in vivo the capacity of activated helper $T$ cell to produce IL$2,{ }^{18}$ even in the presence of glucocorticoids, ${ }^{18}$ which inhibit II-2 production. ${ }^{18}$ The production of $\mathrm{IL}-2$ is decreased in subjects with progression of HIV-1 infection. ${ }^{19}$ DHEA and DHEA sulphate supplements appear to correct the age associated dysregulated production of $\mathrm{T}$ cell lymphokines. ${ }^{20}$ The differentiation of $\mathrm{T}$ lymphocytes into helper cells (T4) or suppressor (T8) depends on the concentrations of androgen. ${ }^{1621}$ Testosterone stimulates the activity and function of $\mathrm{T}$ suppressor cells. ${ }^{22}$ Other data indicate that adult males who are very responsive to androgens produce fewer antibodies. ${ }^{23}$

These epidemiological, clinical, and experimental data suggest that the steroid hormone environment and the immune status of the host may influence the risk of Kaposi sarcoma associated with HIV infection. We therefore studied the serum concentrations of corticoids, progestins, androgens, and oes- 
Table 1 Clinical information on HIV positive men classified according to the CD4 lymphocyte count

\begin{tabular}{|c|c|c|c|c|c|c|c|c|}
\hline Group & $\begin{array}{l}\text { CD4 } \\
\text { range } \\
\left(\text { count } / \mathrm{mm}^{3}\right)\end{array}$ & $\begin{array}{l}\text { Number } \\
\text { of } \\
\text { subjects }\end{array}$ & $\begin{array}{l}\text { Age } \\
\text { (years) }\end{array}$ & $\begin{array}{l}\text { Time since } \\
\text { diagnosis of } \\
\text { HIV } \\
\text { (months) }\end{array}$ & $\begin{array}{l}\text { Previous } \\
\text { infections }\end{array}$ & $\begin{array}{l}\text { Previous } \\
\text { treatment }\end{array}$ & $\begin{array}{l}\text { CD4 } \\
\text { count } \\
\left.\text { (per } \mathrm{mm}^{3}\right)\end{array}$ & $\begin{array}{l}\text { CD8 } \\
\text { count } \\
\left.\text { (per } \mathrm{mm}^{3}\right)\end{array}$ \\
\hline $\mathrm{KS}-$ & $>500$ & $\mathrm{n}=7$ & \multirow{2}{*}{$\begin{array}{l}37 \\
(28-50) \\
39 \\
(26-62)\end{array}$} & \multirow{2}{*}{$\begin{array}{l}26 \\
(15-32) \\
6 \\
(0-23)\end{array}$} & 0 & 0 & \multirow{2}{*}{$\begin{array}{l}944 \\
(781-1366) \\
893 \\
(563-1057)\end{array}$} & \multirow{2}{*}{$\begin{array}{l}1024 \\
(557-1733) \\
772 \\
(450-1246)\end{array}$} \\
\hline $\mathrm{KS}+$ & $>500$ & $\mathrm{n}=5$ & & & 0 & 0 & & \\
\hline $\mathrm{KS}-$ & $500-200$ & $\mathrm{n}=16$ & \multirow{2}{*}{$\begin{array}{l}42 \\
(29-63) \\
36 \\
(23-45)\end{array}$} & \multirow{2}{*}{$\begin{array}{l}42 \\
(0-78) \\
24 \\
(0-43)\end{array}$} & 5 & 3 & \multirow{2}{*}{$\begin{array}{l}329 \\
(209-444) \\
310 \\
(211-422)\end{array}$} & \multirow{2}{*}{$\begin{array}{l}1206 \\
(309-2174) \\
817 \\
(251-2062)\end{array}$} \\
\hline $\mathrm{KS}+$ & $500-200$ & $\mathrm{n}=12$ & & & 2 & 3 & & \\
\hline $\mathrm{KS}-$ & $<200$ & $\mathrm{n}=11$ & $\begin{array}{l}38 \\
(30-44)\end{array}$ & $\begin{array}{l}60 \\
(4-102)\end{array}$ & 2 & 8 & $\begin{array}{l}89 \\
(3-169)\end{array}$ & $\begin{array}{l}565 \\
(211-879)\end{array}$ \\
\hline $\mathrm{KS}+$ & $<200$ & $\mathrm{n}=11$ & $\begin{array}{l}40 \\
(30-44)\end{array}$ & $\begin{array}{l}48 \\
(0-78)\end{array}$ & 2 & 8 & $\begin{array}{l}107 \\
(10-194)\end{array}$ & $\begin{array}{l}966 \\
(239-2208)\end{array}$ \\
\hline
\end{tabular}

KS $-=$ HIV positive men without Kaposi sarcoma; $\mathrm{KS}+=$ HIV positive men with Kaposi sarcoma

trogens in male HIV positive patients with and without Kaposi sarcoma and in HIV negative men. We also determined the steroid hormone concentrations of HIV positive patients with and without Kaposi sarcoma classified according to their absolute CD4 lymphocyte count. These data were analysed to determine if there was any relationship between endogenous serum steroid hormone concentration and the presence of Kaposi sarcoma in a cohort of HIV positive men

\section{Methods}

PATIENTS

Serum samples from Kaposi sarcoma negative and positive patients in each $\mathrm{CD} 4$ range were selected under double blind conditions, according to a single criterion-that the two groups of patients were in the same clinical condition at the time the samples were taken. We then examined the records of the patients for risk factors, age, previous infection, and treatment. All samples were taken from HIV positive patients at the Rothschild hospital (University Paris VI). Twenty eight were HIV positive men with Kaposi sarcoma (group $\mathrm{KS}+$ ) and 34 were HIV positive men without Kaposi sarcoma (group $\mathrm{KS}-$ ). HIV infection was confirmed by western blot. They were classified according to their CD4 lymphocyte counts. The patient data are shown in table 1 . The $\mathrm{KS}+$ group included five patients with $>500$ CD4 cells $/ \mathrm{mm}^{3}, 12$ patients with $500-200 \mathrm{CD} 4$ cells $/ \mathrm{mm}^{3}$, and 11 patients with $<200 \mathrm{CD} 4$ cells $/ \mathrm{mm}^{3}$. The $\mathrm{KS}-$ group included seven patients with $>500$ cells $/ \mathrm{mm}^{3}, 16$ patients with $500-200$ cells $/ \mathrm{mm}^{3}$, and 11 patients with $<200$ cells $/ \mathrm{mm}^{3}$. Two of the $\mathrm{KS}+$ patients were examined twice (first in group 500-200, and then in the group <200 CD4), as they suffered from a recurrence of Kaposi sarcoma after four years of remission. The KS + patient samples were taken within three months of Kaposi sarcoma being diagnosed. All except five were homosexual. In one $\mathrm{KS}+$ patient and two $\mathrm{KS}-$ patients the risk factor was unknown, one KS patient was a drug addict, and one $\mathrm{KS}$ - patient had been transfused. The two groups were of similar age, and had similar previous opportunistic infections and therapy. Only the mean duration of known HIV infection differed; this was because the $\mathrm{KS}+$ patients were seen much earlier than the $\mathrm{KS}-$ patients.
The CD4 cell count indicated that patients with $>500$ CD4 lymphocytes had had no opportunistic infections or treatment; in the 500200 CD4 range, KS + patients had no opportunistic infections but the $\mathrm{KS}$ - patients included one who had had tuberculosis, one with ocular toxoplasmosis, and one with gastric lymphoma. KS + patients with <200 CD4 lymphocytes included one with toxoplasmosis, one with cytomegalovirus (CMV) retinitis, and two with previous Kaposi sarcomas; KS - patients with <200 CD4 lymphocytes included one with toxoplasmosis, one with multifocal leucoencephalitis, and one with a lymphoma. Antiviral therapy was given as follows: in the 500$200 \mathrm{CD} 4$ cell group, one KS + patient had taken zidovudine, and two had taken imuthiol; two KS - patients had taken zidovudine and one had taken imuthiol; in the $<200$ CD4 cell group, six KS + patients had been given antiviral treatment (four zidovudine, two zidovudine followed by DDI), two had taken interferon $\alpha 2 b$ four years earlier; seven $\mathrm{KS}-$ patients had had zidovudine and two had had imuthiol. Five KS + and six KS - patients had primary prophylactic pneumocystosis. Patients were not treated with ketoconazol, glucocorticoids, or interferon at the time the western blots were taken.

The control group consisted of 35 HIV negative male blood donors aged $18-50$ years.

\section{BLOOD SAMPLES}

Blood samples were collected between 0800 and 1000 and allowed to coagulate before separation of serum by centrifugation $(3000 \mathrm{rpm} /$ 10 minutes at $4^{\circ} \mathrm{C}$ ). Serum samples were stored at $-20^{\circ} \mathrm{C}$ until assayed.

\section{STEROID EXTRACTION AND CHROMATOGRAPHIC} FRACTIONATION

(1) Serum samples $(1 \mathrm{ml})$ were extracted for 30 min with $5 \mathrm{ml}$ of organic solvent (ethyl acetate/cyclohexane, $1 / 1$ ) and the aqueous phase was removed by freezing $\left(-20^{\circ} \mathrm{C}\right)$. The organic phase was evaporated to dryness, taken up in $1 \mathrm{ml}$ of solvent system I (benzene/ethanol, 95/5) and placed on a Sephadex LH20 microcolumn $(0.5 \times 6 \mathrm{~cm})$. Progesterone and androstenedione were first eluted with $2.6 \mathrm{ml}$ of solvent I. Oestrone was then eluted with $3.5 \mathrm{ml}$ 
of solvent I followed by $1.0 \mathrm{ml}$ of solvent II (benzene/ethanol, 90/10). Finally, oestradiol and cortisol were eluted with $6 \mathrm{ml}$ of solvent II.

(2) Serum samples $(0.5 \mathrm{ml})$ were extracted as above and placed on Sephadex LH20 microcolumns: testosterone and $17 x$ hydroxyprogesterone $(17 x \mathrm{OH}$-progesterone) were eluted with $5.5 \mathrm{ml}$ of solvent I.

(3) A third series of serum samples $(0.5 \mathrm{ml})$ was extracted with organic solvent (ethyl acetate/ cyclohexane, 1/1) for direct radioimmunoassay (RIA) of dehydroepiandrosterone (DHEA).

(4) DHEA sulphate concentrations were determined directly without extraction. Samples were diluted with radioimmunoassay buffer for RIA.

The yields from these extraction and purification steps were between $70 \%$ and $95 \%$.

\section{RADIOIMMUNOASSAY OF STEROIDS}

Oestrone, oestradiol, progesterone, $17 x \mathrm{OH}-$ progesterone, cortisol, testosterone, androstenedione, DHEA, and DHEA sulphate were assayed using rabbit antisera from Miles, Yeda, Israel (anti-E1 6-thyroglobulin serum, anti$17 \beta$-oestradiol-6-BSA serum, anti-17x OHprogesterone-7-BSA serum, anti-F-21 thyroglobulin serum, anti-testosterone-7- $x$-BSA serum, and anti-androstenedione $7-\boldsymbol{x}$-BSA serum) and rabbit antisera from Biosys, France (anti-progesterone-11HS-BSA, anti-DHEA $15-\mathrm{CH}_{2}-\mathrm{CO}-\mathrm{BSA}$, anti-DHEA sulphate $7-\beta$ CM-BSA). The detection limit was $18 \mathrm{pmol} / 1$ in all cases. All hormones were assayed as described in ${ }^{14}$. DHEA and DHEA sulphate were determined by RIA (Biomérieux kits, Chamberlins-les-Bains, France).

The tritiated steroids $2,4,6,7^{3} \mathrm{H}$ oestrone $(107 \mathrm{Ci} / \mathrm{mmol}), 2,4,6,7^{3} \mathrm{H}$ oestradiol $(99 \mathrm{Ci} /$ $\mathrm{mmol}), 1,2,6,7^{3} \mathrm{H}$ progesterone $(82 \mathrm{Ci} / \mathrm{mmol})$, $1,2,6,7^{3} \mathrm{H} 17 x \mathrm{OH}$ progesterone $(89 \mathrm{Ci} / \mathrm{mmol})$, $1,2,6,7^{3} \mathrm{H}$ cortisol $(85 \mathrm{Ci} / \mathrm{mmol}), 1,2,6,7^{3} \mathrm{H}$ testosterone $(94 \cdot 1 \mathrm{Ci} / \mathrm{mmol}), 1,2,6,7^{3} \mathrm{H}$ androstenedione (96 Ci/mmol), 1,2,6,7 ${ }^{3} \mathrm{H}$ DHEA $(86.6 \mathrm{Ci} / \mathrm{mmol})$, and $1,2,6,7^{3} \mathrm{H}$ DHEA sulphate $(76.8 \mathrm{Ci} / \mathrm{mmol})$ were purchased from the Radiochemical Centre, Amersham. All were $99 \%$ pure; purity was checked by thin layer chromatography. Radioactivity was determined on samples dissolved in $4 \mathrm{ml}$ Opti-Fluor (Packard) by counting in a Packard 1500 liquid scintillation analyser using the internal standard for quench correction.

\section{STATISTICAL ANALYSIS}

The data were analysed by the Wilcoxon nonparametric test and the Student-NewmanKeuls multiple range test. The differences were considered significant at probability $(\mathrm{p})$ values of $<0 \cdot 05$.

\section{Results}

STEROID HORMONE CONCENTRATIONS OF HIV POSITIVE (WITH AND WITHOUT KAPOSI SARCOMA) AND HIV NEGATIVE MEN

The hormone concentrations of HIV negative men (control) and all the members of the two groups of HIV positive men, with and without Kaposi sarcoma, were compared.

Progestins and cortisol-Serum progesterone (fig 1) in the $\mathrm{KS}-$ and the $\mathrm{KS}+$ groups was higher $(125 \%, \mathrm{p}<0.01$, and $105 \%, \mathrm{p}<0.01$, respectively) than in the controls. There was no difference between $\mathrm{KS}+$ and $\mathrm{KS}$ - patients.

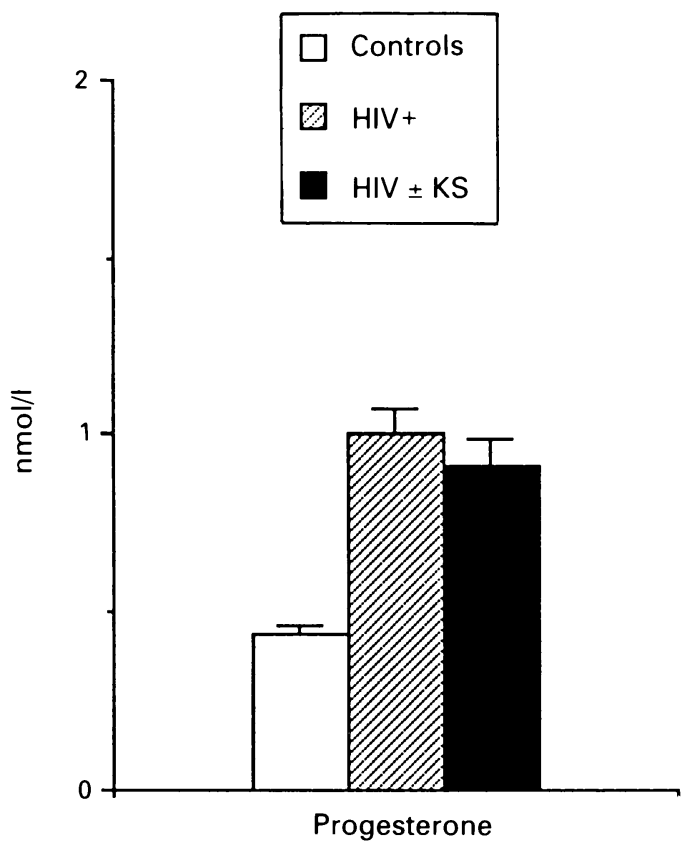

Figure 1 Serum progesterone concentrations in HIV positive men with $(K S+)$ or without $(K S-)$ Kaposi sarcoma and in HIV negative men (controls).

Concentrations were determined by radioimmunoassay. Control, $n=35$ subjects; $K S-, n=34$ subjects; $K S+$, $n=28$ subjects. Error bars $=S E M$.

$K S-v$ control $p<0.01 ; K S+v$ control $p<0.01 ; K S+v$ $K S-: N S$.

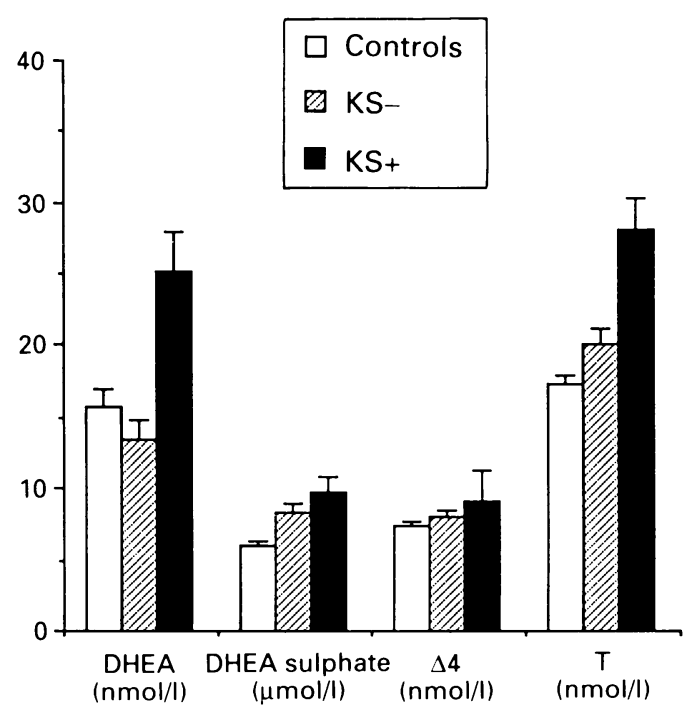

Figure 2 Serum androgens [dehydroepiandrosterone (DHEA), DHEA sulphate, androstenedione (14), and testosterone (T)J in HIV positive men with $(K S+)$ or without (KS-) Kaposi sarcoma and in HIV negative men (controls). Concentrations were determined by radioimmunoassay. Control, $n=35$ subjects; $K S-, n=34$ subjects; $K S+, n=28$ subjects. Error bars =SEM. $K S$ - v control: DHEA sulphate $p<0 \cdot 05 ; K S+v$ control: DHEA, DHEA sulphate, $T p<0 \cdot 01,44 p<0 \cdot 05$; $K S+v K S$ - : DHEA and T $p<0 \cdot 01$. 


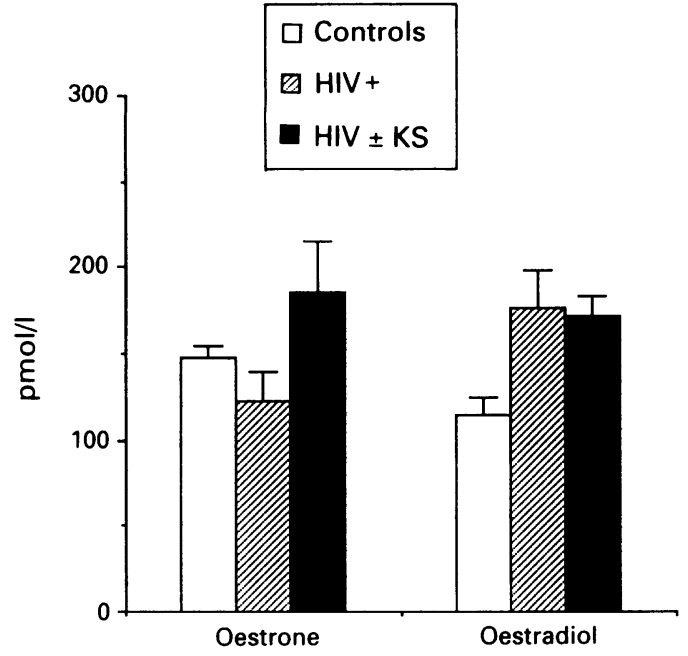

Figure 3 Serum oestrone and oestradiol concentrations in HIV positive men with ( $K S+$ ) or without ( $K S-$ ) Kaposi sarcoma and in HIV negative men (controls). Concentrations were determined by radioimmunoassay. Control, $n=35$ subjects; $K S-, n=34$ subjects; $K S+$, $n=28$ subjects. Error bars $=S E M$.

$K S-v$ control: $E 1 N S, E 2 p<0 \cdot 05 ; K S+v$ control: $E 1$ NS, E2 p<0.05; KS + vKS-:E1 NS, E2 NS.

Serum cortisol and $17 \alpha \mathrm{OH}$-progesterone concentrations in $\mathrm{KS}+$ and $\mathrm{KS}-$ men were not significantly different from control. There was no difference between the $\mathrm{KS}+$ group and the KS - group. The serum cortisol concentrations were: $\mathrm{KS}-, 380(\mathrm{SEM} \mathrm{18 \cdot 8)} \mathrm{nmol} / \mathrm{l}$; $\mathrm{KS}+, 360(19 \cdot 6) \mathrm{nmol} / \mathrm{l}$; control, 337.6(19.3) $\mathrm{nmol} / \mathrm{l}$. The serum $17 \propto \mathrm{OH}$-progesterone concentrations were: $\mathrm{KS}-, 3.5(0.3) \mathrm{nmol} / \mathrm{l} ; \mathrm{KS}+$, $4 \cdot 24(0.3) \mathrm{nmol} / \mathrm{l}$; control, $3.64(0 \cdot 2) \mathrm{nmol} / 1$.

Androgens-The serum concentrations of the androgens DHEA, DHEA sulphate, androstenedione, and testosterone in $\mathrm{KS}+, \mathrm{KS}-$, and controls are shown in fig 2 .

The androgen concentrations were much higher in $\mathrm{KS}+$ men than in controls: DHEA, DHEA sulphate, and testosterone were $60 \%$ above control values $(\mathrm{p}<0.01)$ and androstenedione was $25 \%$ increased $(p<0.05)$. The only androgen that was significantly raised in $\mathrm{KS}$ - patients was DHEA sulphate (35\%, $\mathrm{p}<0.05)$. The DHEA and testosterone concentrations of $\mathrm{KS}+$ patients were higher $(85 \%$ and $40 \%$ respectively, $p<0.01)$ than those of $\mathrm{KS}$ - patients.
Oestrogens (fig 3)-The serum oestradiol concentrations in all groups of HIV positive patients were significantly higher $(50 \%$, $\mathrm{p}<0.05)$ than in controls, but there was no difference between the $\mathrm{KS}+$ and $\mathrm{KS}$ - subjects. The serum oestrone concentrations in HIV positive men were not significantly different from control. There was no difference between the $\mathrm{KS}+$ and $\mathrm{KS}-$ men.

STEROID HORMONE CONCENTRATIONS OF HIV POSITIVE MEN ACCORDING TO THE CD4 LYMPHOCYTE COUNT

The hormone concentration of HIV positive patients with and without Kaposi sarcoma, classified according to their absolute CD4 lymphocyte counts, were compared.

Progestins and cortisol (table 2)-The progesterone concentrations were significantly low $(30 \%, \mathrm{p}<0.05)$ only in $\mathrm{KS}+$ patients in the 500-200 CD4 cells $/ \mathrm{mm}^{3}$ stratum. The $17 \alpha \mathrm{OH}-$ progesterone concentrations were high $(65 \%$, $\mathrm{p}<0.05$ ) only in KS + patients with $>500 \mathrm{CD} 4$ lymphocytes $/ \mathrm{mm}^{3}$. There was no difference in the cortisol concentrations of the two groups according to the CD4 lymphocyte count.

Androgens (fig 4)-Androgens were significantly higher in the KS + men than in the corresponding $\mathrm{KS}-$ men in each of the CD4 lymphocyte count categories. These increases were as follows:

(1) In the $>500$ CD 4 cell stratum, DHEA sulphate increased by $50 \%(\mathrm{p}<0.02)$, DHEA increased by $125 \%(\mathrm{p}<0.02)$, testosterone increased by $85 \%(\mathrm{p}<0.02)$, and androstenedione increased by $20 \%$ (NS).

(2) In the 500-200 CD4 cell stratum, the DHEA and testosterone concentrations were $65 \%(\mathrm{p}<0.01)$ and $35 \%(\mathrm{p}<0.05)$ higher respectively than in the $\mathrm{KS}$ - patients.

(3) In the <200 CD4 stratum, only the DHEA concentrations were increased in the $\mathrm{KS}+$ men $(80 \%, \mathrm{p}<0.05)$.

Oestrogens (table 3)-The serum oestrone and oestradiol concentrations in the $\mathrm{KS}+$ and $\mathrm{KS}$ - patients were not significantly different, regardless of the CD4 cell count.

Table 2 Serum progestin and cortisol levels in HIV positive men. Values are means (SEM)

\begin{tabular}{|c|c|c|c|c|c|}
\hline Group & $\begin{array}{l}\text { CD4 range } \\
\left.\text { (count } / \mathrm{mm}^{3}\right)\end{array}$ & $\begin{array}{l}\text { Number of } \\
\text { subjects }\end{array}$ & $\begin{array}{l}\text { Progesterone } \\
\text { (nmolll) }\end{array}$ & $\begin{array}{l}\text { 17xOH-progesterone } \\
(\mathrm{nmol} / \mathrm{l})\end{array}$ & $\begin{array}{l}\text { Cortisol } \\
(\text { nmolll })\end{array}$ \\
\hline $\begin{array}{l}\mathrm{KS}- \\
\mathrm{KS}+\end{array}$ & $\begin{array}{l}>500 \\
>500\end{array}$ & $\begin{array}{l}\mathrm{n}=7 \\
\mathrm{n}=5\end{array}$ & $\begin{array}{l}1.02(0 \cdot 12) \\
1 \cdot 00(0 \cdot 2)\end{array}$ & $\begin{array}{l}2.42(0.33) \\
4.10(0.60)^{*}\end{array}$ & $\begin{array}{l}392 \cdot 0(38 \cdot 6) \\
401 \cdot 6(61)\end{array}$ \\
\hline $\begin{array}{l}\mathrm{KS}- \\
\mathrm{KS}+\end{array}$ & $\begin{array}{l}500-200 \\
500-200\end{array}$ & $\begin{array}{l}\mathrm{n}=16 \\
\mathrm{n}=12\end{array}$ & $\begin{array}{l}1.05(0.11) \\
0.70(0 \cdot 10)^{*}\end{array}$ & $\begin{array}{l}3.94(0.45) \\
4.70(0.60)\end{array}$ & $\begin{array}{l}361 \cdot 6(22) \\
386 \cdot 7(32 \cdot 6)\end{array}$ \\
\hline $\begin{array}{l}\mathrm{KS}- \\
\mathrm{KS}+\end{array}$ & $\begin{array}{l}<200 \\
<200\end{array}$ & $\begin{array}{l}\mathrm{n}=11 \\
\mathrm{n}=11\end{array}$ & $\begin{array}{l}0.94(0 \cdot 13) \\
1 \cdot 10(0.15)\end{array}$ & $\begin{array}{l}3.64(0.70) \\
3.80(0.50)\end{array}$ & $\begin{array}{l}382 \cdot 5(44 \cdot 2) \\
312 \cdot 0(28 \cdot 07)\end{array}$ \\
\hline
\end{tabular}

Serum progesterone, $17 x \mathrm{OH}$ progesterone, and cortisol concentrations in HIV positive men with Kaposi sarcoma (KS + ) or without Kaposi sarcoma (KS - ), grouped according to their CD4 lymphocyte count, were determined by radioimmunoassay. ${ }^{*} \mathrm{p}<0.05 v \mathrm{KS}-$ 

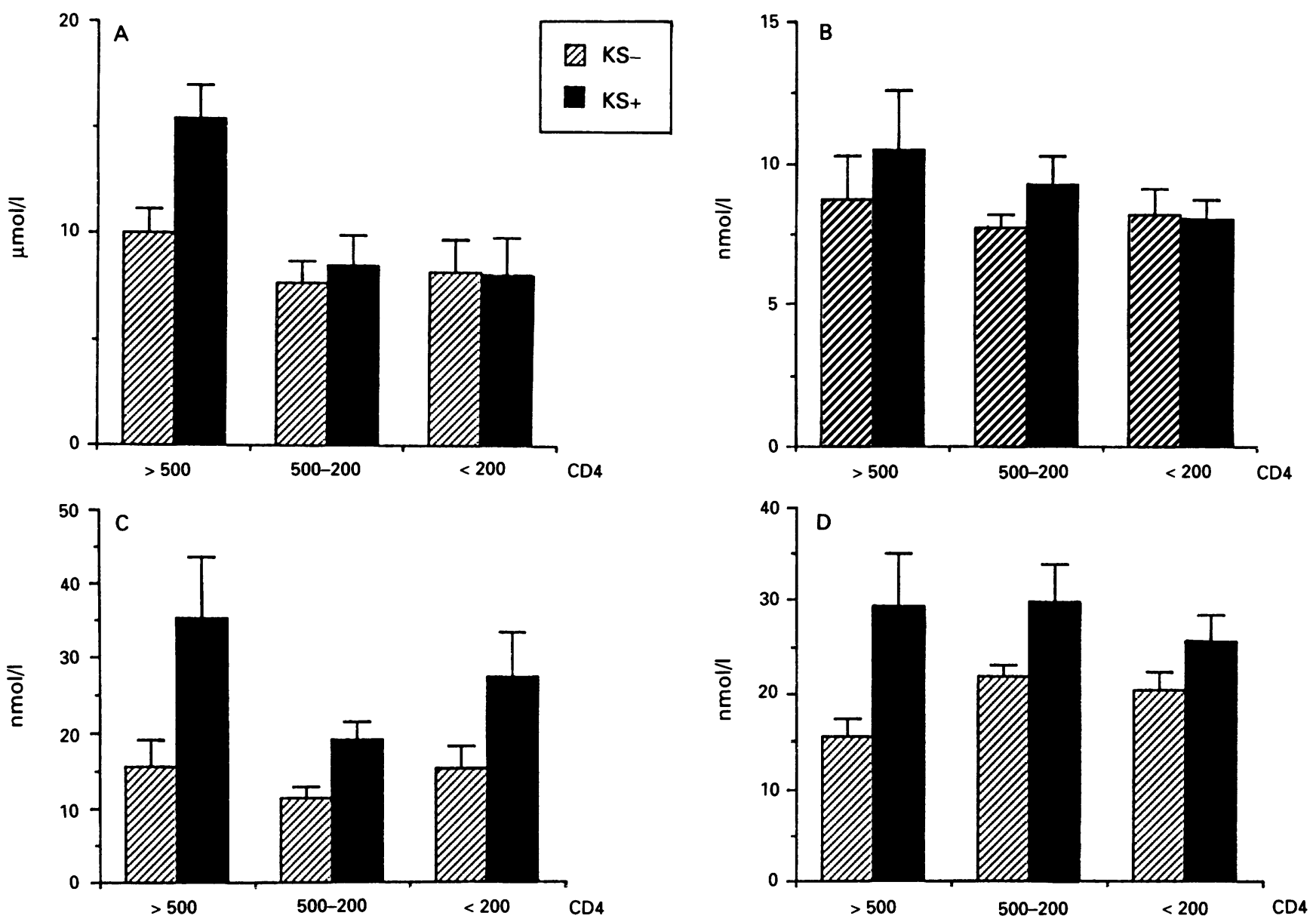

Figure 4 Serum androgens [(A) dehydroepiandrosterone (DHEA) sulphate; (B) androstenedione ( 44$) ;(C)$ DHEA; (D) testosterone] in HIV positive men with $(K S+)$ and without $(K S-)$ Kaposi sarcoma. Concentrations were determined by radioimmunoassay. Error bars $=S E M$. The distribution of patients according to CD4 count is shown in table 1.

$>500 \mathrm{CD4}, \mathrm{KS}+v \mathrm{KS}-:$ DHEA sulphate, DHEA, testosterone p<0.01, $44 \mathrm{NS} ; 500-200 \mathrm{CD} 4, \mathrm{KS}+v \mathrm{KS}-:$ DHEA p<0.01, testosterone $p<0 \cdot 05 ;<200 C D 4, K S+v K S-: D H E A p<0 \cdot 05$.

Table 3 Serum oestrogen concentrations in HIV positive men. Values are means (SEM)

\begin{tabular}{lllll}
\hline Group & $\begin{array}{l}\text { CD4 range } \\
\left(\text { count/mm } \text { m }^{3}\right.\end{array}$ & $\begin{array}{l}\text { Number of } \\
\text { subjects }\end{array}$ & $\begin{array}{l}\text { Oestrone } \\
\text { (pmolll) }\end{array}$ & $\begin{array}{l}\text { Oestradiol } \\
\text { (pmolll) }\end{array}$ \\
\hline KS - & $>500$ & $\mathrm{n}=7$ & $111(22)$ & $205(77)$ \\
KS + & $>500$ & $\mathrm{n}=5$ & $222(78)$ & $143(29)$ \\
$\mathrm{KS}-$ & $500-200$ & $\mathrm{n}=16$ & $107(18)$ & $147(18)$ \\
$\mathrm{KS}+$ & $500-200$ & $\mathrm{n}=12$ & $126(33)$ & $165(15)$ \\
$\mathrm{KS}-$ & $<200$ & $\mathrm{n}=11$ & $152(41)$ & $187(40)$ \\
$\mathrm{KS}+$ & $<200$ & $\mathrm{n}=11$ & $237(55)$ & $195(22)$ \\
\hline
\end{tabular}

Serum oestrone and oestradiol concentrations in HIV positive men with Kaposi sarcoma (KS +) or without Kaposi sarcoma (KS -), grouped according to their CD4 lymphocyte count, were or without Kaposi sarcoma (KS-),
determined by radioimmunoassay.
HIV positive patients with Kaposi sarcoma had significantly higher serum adrenal androgen (DHEA and DHEA sulphate) and gonadal androgen (testosterone) concentrations than the HIV positive men without Kaposi sarcoma, or the HIV negative men. This difference was still evident when the patients were classified according to their CD4 lymphocyte count. The serum DHEA and testosterone concentrations of the $\mathrm{KS}+$ patients were higher than those of $\mathrm{KS}$ - patients, whatever the CD4 lymphocyte count. The increase in androgen levels was much greater in those $\mathrm{KS}+$ subjects with more than $500 \mathrm{CD} 4$ cells per $\mathrm{mm}^{3}$. In these patients with Kaposi sarcoma but without other clinical problems, all the androgen concentrations were higher than in HIV positive patients without Kaposi sarcoma. This difference was very significant for DHEA, DHEA sulphate and testosterone, but not significant for androstenedione, perhaps because of the small number of patients studied. High androgen levels have been reported in male subjects in the early stages of HIV infection (stages II and III according to CDC Atlanta criteria). ${ }^{14}$ The present study shows that the decrease in the absolute CD4 cell count and progression to AIDS is accompanied by a fall in the serum androgen concentrations. There is also a significant linear correlation between the CD4 
cell count and the serum concentrations of DHEA sulphate only in the KS + patients $(r=$ $0.4155, p<0 \cdot 01)$. Both the DHEA and testosterone levels of KS + subjects with 500-200 CD4 cells per $\mathrm{mm}^{3}$ were higher than those of the $\mathrm{KS}$ - patients. But in the $\mathrm{KS}+$ subjects with $<200$ CD4 cells $/ \mathrm{mm}^{3}$, only the DHEA concentration was higher than in $\mathrm{KS}-$ patients. A decrease in DHEA has been associated with increased risk of progression to AIDS in men with $200-499 \mathrm{CD} 4$ cells $/ \mathrm{mm}^{3} .15$ A longitudinal study ${ }^{24}$ indicates that there is a correlation between the decrease in serum DHEA in HIV-1 infected men and progression to AIDS. The association of other infections with Kaposi sarcoma could induce the fall in androgens, as seen in human septic and experimental endotoxin shock. ${ }^{2526}$

Studies on the relationship between the immune response and steroid hormones suggest that androgens regulate the immune system, influencing lymphocyte proliferation and function, ${ }^{1721}$ and controlling the production of lymphokines. ${ }^{1618}$ An excess of androgens should stimulate suppressor $\mathrm{T}$ cell function at the expense of helper $T$ cell function. ${ }^{1621}$ The adrenal androgens, DHEA and DHEA sulphate, enhance the capacity of activated $T$ cells to produce interleukin- 2 and $\gamma$-inferferon, and reverse glucocorticoid induced inhibition of these important lymphokines. The high androgen levels observed in $\mathrm{KS}+$ patients, particularly in early stages of the disease (with $>500 \mathrm{CD} 4$ cells $/ \mathrm{mm}^{3}$ ), may affect the immune system by inducing an abnormal cytokine profile and increased CD8 proliferatiion.

Various clinical and epidemiological data have been associated with Kaposi sarcoma, for example, gender, ${ }^{12}$ age,${ }^{2}$ homosexuality or bisexuality, ${ }^{3}$ and immunosuppressive therapy. ${ }^{8}$ Whatever the exact mechanism by which $\mathrm{Ka}$ posi sarcoma develops, this report suggests that the clinical progression of Kaposi lesions is closely associated with the hormonal status, notably the androgen levels, of the patients. Further studies on the relationship between androgen concentrations, the cytokine profile, and $T$ cell proliferation, activity, and function in HIV associated Kaposi sarcoma should indicate the exact position of androgens in the cause and effect interactions leading to this disease. Hence a clear understanding of the hormonal environment may provide a sound basis for the development of new therapeutic strategies.

This work was supported by grants from UER Xavier Bichat (University Paris VII). The authors are grateful to Dr Becker and Dr Elias (Centre de Transfusion Sanguine, Hôpital Bichat, Paris) for the blood samples. We thank Dr Owen Parkes for correcting the manuscript and Mrs P Ho Kuo Chu for secretarial assistance.

1 Safrai B. Pathophysiology and epidemiology of epidemic Kaposi's sarcoma. Semin Oncol 1987;14:7-12.

2 Beral V, Peterman TA, Berkelman RL, Jaffe HW. Kaposi's sarcoma among patients with AIDS: a sexually transmitted infection? Lancet 1990;335:123-8.
3 De Jarlais DC, Marmor M, Thomas P, Chamberland M, Zolla-Pazner S, Sencer DJ. Kaposi's sarcoma among four different AIDS risk groups. $N$ Engl $\mathcal{F}$ Med 1984;310:1119.

4 Miles SA, Rezai AR, Salazar-Gonzales JF, Van der Meyden M, Stevens RH, Logan DM, et al. AIDS Kaposi's sarcomaderived cells produce and respond to interleukin-6. Proc Natl Acad Sci USA 1990;87:4068-72.

5 Ensoli B, Nakamura S, Salahuddin SZ, Biberfeld P, Larsson L, Beaver B, et al. AIDS-Kaposi's sarcoma-derived cells express cytokines with autocrine and paracrine growth express cytokines with autocrin
effects. Science 1989;243:223-6.

6 Gill PS, Loureiro C, Bernstein-Singer M, Rarick MU, Sattler F, Levin AM. Clinical effect of glucocorticoids on Kaposi sacoma related to AIDS. Ann Intern Med 1989; 11:937-40.

7 Bruet A, Mahe A, Sei JF, Mathe C, Felsenheld C, Lechevalier L, et al. Sarcome de Kaposi compliquant une corticothérapie au long cours pour asthme sévère. Rev Med Interne 1990;11:322-4.

8 Harwood A, Osoba D, Hofstader S, Golgstein MB, Cardella $\mathrm{CJ}$, Holecek MJ, et al. Kaposi's sarcoma in recipients of renal transplants. Am $\mathcal{f}$ Med 1979;67:759-65.

9 Vogel J, Hinrichs SH, Reynolds RK, Luciw PA, Jay G. The HIV tat gene induces dermal lesions resembling Kaposi's sarcoma in transgenic mice. Nature 1988;335:606-11.

10 Membreno L, Irony I, Dere W, Klein R, Biglieri EG, Cobb E. Adrenocortical function in acquired immunodeficiency syndrome. F Clin Endocrinol Metab 1987;65:482-7.

11 Christeff N, Michon C, Goertz G, Hassid J, Matheron S, Girard JP, et al. Abnormal free fatty acids and cortisol concentrations in the serum of AIDS patients. Eur $\mathcal{F}$ Cancer Clin Oncol 1988;24:1179-83.

12 Croxson TS, Chapman WE, Miller LK, Levit CD, Senie $R$, Zummoff B. Changes in the hypothalamic-pituitarygonadal axis in human immunodeficiency virus-infected
homosexual men. $¥$ Clin Endocrinol Metab 1989;68:31721.

13 Villette JM, Bourin P, Doinel C, Mansour I, Fiet J, Boudou P, et al. Circadian variations in plasma levels of hypophyseal, adrenocortical and testicular hormones in men infected with human immunodeficiency virus. $f$ Clin Endocrinol Metab 1990;70:572-7.

14 Christeff N, Gharakhanian S, Thobie N, Rozenbaum W, Nunez EA. Evidence for changes in adrenal and testicular steroids during HIV infection. $f$ AIDS 1992;5:841-6.

15 Jacobson MA, Fusaro RE, Galmarini M, Lang W. Decreased serum dehydroepiandrosterone is associated with an increased progression of human immunodeficiency virus creased progression of human immunodeficiency virus Dis $1991 ; 164: 864-8$.

16 Araneo BA, Dowell T, Diegel M, Daynes RA. Dihydrotestosterone exerts a depressive influence on the production of interleukin-4 (IL-4), IL-5, and $\gamma$-interferon, but not II- 2 by activated murine T cell. Am Soc Hematol 1991;78:688-99.

17 Grossman CJ. Regulation of the immune system by sex steroids. Endocrine Rev 1984;5:435-55.

18 Daynes RA, Dudley DJ, Araneo BA. Regulation of murine lymphokine production in vivo II. Dehydromurine lymphokine production in vivo II. Dehydroepiandrosterone is a natural enhancer of interleukin 2
synthesis by helper T cells. Eur $₹$ Immunol 1990;20:793802.

19 Clerici M, Hakim FT, Venzon DJ, Blatt S, Hendrix CW, Wynn TA, et al. Changes in interleukin-2 and interleukin4 production in asymptomatic human immunodeficiency virus-seropositive individuals. $\mathcal{F}$ Clin Invest 1993;91:75965.

20 Araneo BA, Woods ML, Daynes RA. Reversal of the immunosenescent phenotype by dehydroepiandrosterone: hormone treatment provides an adjuvant effect on the immunization of aged mice with recombinant hepatitis $B$ surface antigen. F Infect Dis 1993;167:834-40.

21 Lehmann D, Siebold K, Emmons LR, Muller HJ. Androgens inhibit proliferation of human peripheral blood lymphocyt

22 Weinstein Y, Bercovich Z. Testosterone effect on bone marrow, thymus and suppressor $T$ cells in the $(\mathrm{NZB} \times \mathrm{NZW}) \mathrm{F} 1$ mice: its relevance to autoimmunity. $\mathcal{f}$ Immunol 1991;126:998-1002.

23 Cohn DA. Sensitivity to androgen. A possible factor in sex differences in the immune response. Clin Exp Immunol 1979;38:218-27.

24 Mulder JW, Frissen J, Krijnen P, Endert E, de Wolf F, Goudsmit $\mathrm{J}$, et al. Dehydroepiandrosterone as predictor for progression to AIDS in asymptomatic human immunodeficiency virus-infected men. $\mathcal{F}$ Infect Dis 1992;165: 413-8.

25 Christeff N, Benassayag C, Carli-Vielle C, Carli A, Nunez EA. Elevated oestrogen and reduced testosterone levels EA. Elevated oestrogen and reduced testosterone levels
in the serum of male septic shock patients. $₹$ Steroid in the serum of male sept

26 Christeff N, Auclair MC, Benassayag C, Carli A, Nunez EA. Endotoxin-induced changes in sex steroid hormone levels in male rats. $\mathcal{F}$ Steroid Biochem 1987;26:61-71. 